Journal of Social Sciences (COES\&RJ-JSS)

ISSN (E): 2305-9249 ISSN (P): 2305-9494

Publisher: Centre of Excellence for Scientific \& Research Journalism, COES\&RJ LLC

Online Publication Date: $1^{\text {st }}$ January 2015

Online Issue: Volume 4, Number 1, January 2015

http://www.centreofexcellence.net/J/JSS/JSS Mainpage.htm

\title{
Analysis of the Current State of Online Reputation of Public Institutions and the Possibilities of Its Improvement
}

\author{
Peter Dorčák, ${ }^{a}$ František Pollák, ${ }^{a}$ Nella Svetozarovováa ${ }^{a}$ \\ ${ }^{a}$ University of Prešov in Prešov, Faculty of Management, Department of Marketing and \\ International Trade, Konštantínova 16, Prešov, Slovak Republic, 08001
}

\begin{abstract}
:
The article deals with the issue of reputation, especially with the focus on a current phenomenon of reputation in the digital world of the Internet - online reputation - of selected public institutions operating in the domestic market. Sentiments of specifically selected twenty public universities and colleges are rated in two dimensions: virtual and real. The primary aim of this article is to investigate the existence of a statistically significant correlation between reputation of researched subjects in the real and virtual world. In conclusion paper presents options and recommendations for optimizing virtual reputation and highlights the differences of perception of reputation in the traditional and in the virtual market by understanding the differences between factors affecting traditional reputation and factors affecting reputation in digital world.
\end{abstract}

Keywords:

online reputation, sentiment, public institution, marketing.

\section{Citation:}

Dorcek, Peter; Pollák , František; Svetozarovová, Nella (2015); Analysis of the Current State of Online Reputation of Public Institutions and the Possibilities of Its Improvement; Journal of Social Sciences (COES\&RJ-JSS), Vol.4, No.1, pp: 664-673.

http://dx.doi.org/10.17632/gsk2xjkw22.1 


\section{Introduction}

Reputation is a concept commonly used in marketing management and it generally means an overall presence on the market. From the point of view of Internet we can compare it to leaving footprints. All activities are interconnected and complement one another. ${ }^{1}$ Each institution has a reputation or online reputation, whether they want it, or not; the reputation does exist. ${ }^{2}$ If an entrepreneurs running their own businesses (or managing an institutions), they should not leave their reputation to chance. It is their ultimate responsibility. Company's reputation is considered to be very valuable asset. As George Washington once said: "With a reputation you can do anything without one, nothing". ${ }^{3}$ However, if we consider corporate reputation, its definition is a bit complicated. ${ }^{4}$ Balmer and Greyser ${ }^{5}$ characterize corporate reputation as such which is created over time based on what the organization did and how it behaved. Company's or corporate reputation only reflects relative standing of the company, both internally with its employees and externally with other stakeholders, in both its competitive and institutional environments. Highhouse defines corporate reputation as a global, stable over time, evaluative judgement about a company that is shared by multiple constituencies. ${ }^{6}$ It is a pure reaction of customers, investors, employees and other stakeholders. It is a collective judgement of individual impressions.?

\section{The issue of reputation in the context of trust}

Trust fulfils every organisation in a million of different ways. No institution can function without it. Trust is a strong belief that we can rely on someone. ${ }^{8}$ Shaw offers alternative definition (in Armstrong 2007); he defines the concept of trust as a belief that those on whom we depend will meet our expectations of them. ${ }^{9}$ These expectations depend on our critical judgement of other person's responsibility to meet our needs. Tavakolifard ${ }^{10}$ claims that generally accepted definition of trust is still missing despite comprehensive studies of philosophers, sociologists and psychologists. It is easier to identify individual features of trust than to determine exactly what it means. We agree with the definition by Gambetta ${ }^{11}$ who argues that trust (or symmetrically, distrust) is a particular level of the subjective probability with which an agent assesses that another agent or group of agents will perform a particular action, both before he can monitor such action (or independently of his capacity ever to be able to monitor it) and in a context in which it affects his own action. An agent is generally an individual or a thing (entity) which affects the environment or other agents and has characteristic and its own targets which it strives to achieve. The contextuality of trust means that the trust of entity "A" towards entity "B" is always dependent on certain context "C". We'd like to point out the work of Jøsang ${ }^{12}$ who deals with "the issue of trust" (in terms of creating trust, establishing credibility and making decisions on the basis of credibility). Jøsang further states that trust is an oriented relationship between two parties called the subject and the object. The term oriented is used in the sense of clear distinction of resources (subject) and goals (object) of the relationship. The authors further define two types of trust: Context-independent (reliability trust) - where trust is the subjective probability by which an individual " $\mathrm{A}$ " expects that another individual "B" performs a given action on which its welfare depends; and Context-dependent (decision-trust) - Trust is the extent to which one party is willing to depend on something or somebody in a given situation with a feeling of relative security, even though negative consequences are possible.

\subsection{Classification of models based on trust and reputation}

Jordi Sabater and Carles Sierra ${ }^{13}$ in their work Review on Computa-tional Trust and Reputation Models have specified classifications which focus on major models and try to find common features based on which individual classification methods and their 
categories are designed. Basic classification criterion is the so called model type. Model type means whether the model works with trust or a reputation:

-models of trust - work only with trust,

-models of reputation - work only with reputation,

-hybrid models - work both with trust and reputation.

According to these authors, models can be classified on the basis of determining the origin of information (knowledge) which is used for the evaluation of reputation, as well as confidence.

\subsection{Classification of models based on trust and reputation}

Companies and organizations in common have invested large amounts of financial resources and hired agencies and marketing professionals to prepare communication campaigns to support such brand image that would create an incentive for the customers to make purchases. ${ }^{14}$ This argument is supported by Smaiziene and Jucevicius ${ }^{15}$ who claim that companies prefer to focus primarily on the image and leave the reputation behind. Grant Leboff mentions that the image is not a guarantee of positive comments and recommendations. ${ }^{14}$ These will only be achieved due to good reputation. In other words, the foundation of modern marketing is not the image which the organization strives to create, but the reputation which it has actually established. As regards the image and reputation, Bennet and Kottasz point out time dimension (time of creation) as the main characteristics which distinguish these two constructs. In other words, organization's image can be created in a short time. Reputation is generated in a longer time frame, and therefore cannot be changed or redirected as quickly as the image (In: Smaiziene, Jucevicius 2009). ${ }^{15}$ Such an approach is also supported by Jackson ${ }^{16}$ who argues that the time of establishment or creation is one of the main differences between the image (short time of creation) and reputation (long time of creation). Fill ${ }^{17}$ perceives reputation as wider set of images. He is also of the opinion that changing reputation is more time consuming and difficult while image can be influenced much faster. Therefore, it may be said that reputation and image are not synonymous, as some authors point out, yet they are closely related and interdependent elements.

\subsection{Creation of reputation}

Reputation of any organization is composed of three forms, i.e. primary, secondary and cyclic. $^{18}$ Fombrun and Foss $^{19}$ defined reputation as collective assessment of the organization's ability to provide valuable product, service or other value to a group of customers. They have developed a scale that measures corporate reputation, which they call corporate reputation quotient (RQ). RQ is a complex method of measuring corporate reputation. ${ }^{20}$ The building of corporate reputation has been primarily attributed to the area of marketing and communication. Nowadays the corporate reputation has been integrated into human resource management and corporate strategy. Reputation is communicated to the public by the organization's managers. It is generally accepted that reputation begins from the inside out. ${ }^{21}$ Fombrun and Foss ${ }^{19}$ noted that it is good if the organization takes care of its reputation, and they emphasized the following factors:

1.The Principle of Distinctiveness - Strong reputations result when organizations own a distinctive position in the minds of customers.

2.The Principle of Focus - Strong reputations result when organizations focus their actions and communications around a single core theme.

3.The Principle of Consistency - Strong reputations result when organizations are consistent in their actions and communications with internal, as well as external environment. 
4.The Principle of Transparency - Strong reputations result when organizations are transparent in the way they conduct their affairs. In particular, organizations should be perceived as open and honest in their business activities. Transparency requires communication - a lot of it.

\subsection{Reputation in online environment}

Reputation in life and business is everything. It means that reputation is very fragile and one mistake may sometimes cause irreversible damage. This is especially true in the digital world, where radical transparency and demanding customers have the greatest power. If the Internet offers consumers a new way to share information about companies and brands, then it also allows the companies to control information about them. ${ }^{1}$ Consumers are able to obtain information on potential suppliers and products, but they can also create new content on the Internet which may affect the perception of other consumers and stakeholders of the respective organization. Negative comments on the Internet can quickly and seriously damage the image and reputation of the brand. ${ }^{22} \mathrm{eWOM}$ (electronic word of mouth) is an important part of online reputation. This form of communication may be defined as any positive or negative statement made by potential, actual or former customers about a product or organization via the Internet. ${ }^{23}$

Jun Loayza ${ }^{24}$ presents basic principles of online reputation management which he divides into various segments such as Quick Fix, Long-Lasting, Content Driven and Relationship Driven.

\section{Analysis of reputation of selected entities in Slovak real and virtual market}

Virtual reputation management or, in other words Online reputation management (ORM in short) has ceased to be a novelty or an unknown concept in Slovakia. ORM has been applied in many industries such as banking and insurance. The results of these surveys provide a reliable and current view of virtual presentation of organizations as well as the image of their virtual identities. The level of positive online reputation is not only a source of information for organizations, but also an important factor influencing the decisionmaking processes of consumers. Methodology called "sentiment analysis" was used to assess virtual reputation. ${ }^{18}$ Using the chosen methodology, online reputation of top twenty public universities and colleges on Slovak market (as the best representatives of entities from education field) was analyzed. The presented methodology can then be used for the purpose of ascertaining the online reputation of various entities such as SMEs, public institutions and even individuals using the Internet for personal branding. The sequence of the reputation measurement process begins by defining representatives of the segment. We have selected representatives of public universities and colleges in Slovakia in this case. Subsequently, virtual identity of these entities using the Google search engine was studied. For the purposes of the sentiment analysis the first 10 search results was taken into account. To ensure objectivity of the results that may be biased due to the tendency of search engines to personalize the search through the history of Internet activity, the proxy anonymizer was used in order to increase anonymity. Only organic results were included in the survey, paid contextual advertisements of the Adwords system were excluded. In determining the sentiment the numbers of positive reviews on social networks were not taken into account. Only the fact that an institution owns a profile on any of the virtual social networks was taken into account. The nature of institutions descriptions on the Wikipedia portal was also not taken into account. Only the fact that Wikipedia mentions an institution was taken into account. In both cases, these results were assigned neutral sentiment. If the search engine found, besides an official institution's web site, web pages 
of institution's faculties or entities associated with such institution on other places in a search, these results were assigned neutral sentiments. If the institution's web site occurred in several places within the search, only the first occurrence was taken into account, where the following occurrences of institution's web site were assigned neutral character. Well known and well established names of selected entities were used as search phrases in full regardless of their home sites. One of the main factors in the evaluation process was sentiment of the results. This can be loosely defined as the nature of results found by entering keywords. Positive, neutral, but also negative feedback can be found in the results. These sentiments, as well as positions on which they were displayed, provided a picture of research subjects, and thus ultimately determine its online reputation. Sentiment of individual results in the Top 10 is clearly shown in the table with a short commentary. At the same time, scores are allocated to each position on the basis of sentiment in the following table:

Table 1 Sentiment individual results / position of results. ${ }^{18}$

\begin{tabular}{|l|l|l|l|l|l|l|l|l|l|l|}
\hline $\begin{array}{l}\text { Sentiment / } \\
\text { Position of the result }\end{array}$ & $\mathbf{1}$ & $\mathbf{2}$ & $\mathbf{3}$ & $\mathbf{4}$ & $\mathbf{5}$ & $\mathbf{6}$ & $\mathbf{7}$ & $\mathbf{8}$ & $\mathbf{9}$ & $\mathbf{1 0}$ \\
\hline $\begin{array}{l}\text { Positive sentiment } \\
+\end{array}$ & 20 & 19 & 18 & 17 & 16 & 15 & 14 & 13 & 12 & 11 \\
\hline $\begin{array}{l}\text { Custom web site of the } \\
\text { organization } \\
\mathrm{X}\end{array}$ & 10 & 9 & 8 & 7 & 6 & 5 & 4 & 3 & 2 & 1 \\
\hline $\begin{array}{l}\text { Neutral sentiment } \\
\mathbf{\pm}\end{array}$ & 2 & 2 & 2 & 2 & 2 & 2 & 2 & 2 & 2 & 2 \\
\hline $\begin{array}{l}\text { Negative sentiment } \\
-\end{array}$ & -20 & -19 & -18 & -17 & -16 & -15 & -14 & -13 & -12 & -11 \\
\hline
\end{tabular}

The table shows chronological sequence of awarding points to analyzed entities. Positive feedback or sentiment increases score. The higher the position of this sentiment in search results, the more points it has. Similarly, but with the opposite effect, this applies to identifying negative sentiment. Points are deducted as follows: the higher the position of the sentiment in search results, the bigger the point deduction resulting in rapidly deteriorating reputation. Within the overall evaluation individual sentiments are then totaled, and the sum indicates the strength of sentiment of all ten search engine results for a given entity. The resulting sum of sentiments represents the overall level (strength) of online reputation. For the purpose of comparison entities were then arranged in ascending order based on the overall level of their online reputation in the virtual environment of the Slovak Internet. For better clarity the methodology is supplemented by the parameter of percentage evaluation of the score relative to the maximum possible number of points obtained within the analysis of sentiment (maximum possible number of points $=155,1 \mathrm{p}$ $=0.645 \%$ ). For the purpose of comparison of real and virtual (online) reputation of universities and colleges operating on the Slovak market, rating of the ARRA agency was used for the real reputation. Slovak Academic Ranking and Rating Agency (ARRA) ${ }^{25}$ annually evaluates the quality of education and research in the faculties of public colleges operating in Slovakia, and the result of this evaluation is a ranking of each institution of a given Department on the basis of comparison of quantity and quality indicators of education and research. The basic principle of assessment is divided into the following 5 indicators: 1) Education (number of students, teachers, quality of the teaching staff); 2) Attractiveness of the study (interest in the study, proportion of foreign students, mobility, unemployment); 3) Research (number of publications and citations, average citation); 4) 
Doctoral studies (proportion of graduates, proportion of the student population, the ratio of scientific output and number of doctoral candidates); and 5) Grant success rate (domestic grants, international grants, total income from grants for a creative worker). The following table presents the results of the overall evaluation of sentiments of twenty selected Slovak universities / public colleges. Researched subjects were assigned rankings based on values obtained for real and virtual reputation, which were subsequently subjected to empirical investigation to determine whether there is any statistically significant dependence between the rankings of real and virtual reputation.

Table 2 Total score sentiments twenty Slovak public universities / colleges.

\begin{tabular}{|c|c|c|c|c|c|c|c|c|c|c|c|c|c|c|}
\hline No & $\begin{array}{l}\text { Public } \\
\text { universities/colleges }\end{array}$ & 1 & 2 & 3 & 4 & 5 & 6 & 7 & 8 & 9 & $\begin{array}{l}1 \\
0\end{array}$ & $\begin{array}{l}\text { Score } \\
\text { (on-line) } \\
\text { in } \\
\text { points / \% }\end{array}$ & $\begin{array}{l}* \text { ARRA } \\
\text { Average } \\
\text { in } \%\end{array}$ & $\begin{array}{l}* * \text { ARRA } \\
\text { Ranking } \\
\text { position }\end{array}$ \\
\hline 1 & $\begin{array}{l}\text { J. Selye University in } \\
\text { Komarno }\end{array}$ & $\mathrm{X}$ & \pm & \pm & \pm & \pm & + & \pm & \pm & \pm & \pm & $41 / 26,45$ & 32,7 & 19 \\
\hline 2 & $\begin{array}{l}\text { Comenius University } \\
\text { in Bratislava }\end{array}$ & $\mathrm{X}$ & \pm & \pm & \pm & \pm & \pm & + & \pm & \pm & \pm & $40 / 25,8$ & 58,06 & 3 \\
\hline 3 & $\begin{array}{l}\text { Technical University in } \\
\text { Zvolen }\end{array}$ & $\mathrm{X}$ & \pm & \pm & \pm & \pm & \pm & + & \pm & \pm & \pm & $40 / 25,8$ & 47,35 & 8 \\
\hline 4 & $\begin{array}{l}\text { Matej Bel University } \\
\text { in Banska Bystrica }\end{array}$ & $\mathrm{X}$ & \pm & \pm & \pm & \pm & \pm & \pm & + & \pm & \pm & $39 / 25,16$ & 45,38 & 12 \\
\hline 5 & $\begin{array}{l}\text { University of } \\
\text { Veterinary Medicine } \\
\text { and Pharmacy in } \\
\text { Kosice }\end{array}$ & $\mathrm{X}$ & \pm & \pm & \pm & \pm & \pm & \pm & \pm & + & \pm & $38 / 24,51$ & 72,3 & 1 \\
\hline 6 & $\begin{array}{l}\text { Pavol Jozef Safarik } \\
\text { University in Kosice }\end{array}$ & $\mathrm{X}$ & \pm & \pm & \pm & \pm & \pm & \pm & \pm & \pm & + & $37 / 23,87$ & 56,16 & 4 \\
\hline 7 & $\begin{array}{l}\text { University of Presov in } \\
\text { Presov }\end{array}$ & $\mathrm{X}$ & \pm & \pm & \pm & \pm & \pm & \pm & \pm & \pm & + & $37 / 23,87$ & 40,03 & 16 \\
\hline 8 & $\begin{array}{l}\text { University of SS. Cyril } \\
\text { and Methodius in } \\
\text { Trnava }\end{array}$ & $\mathrm{X}$ & \pm & \pm & \pm & \pm & \pm & \pm & \pm & \pm & + & $37 / 23,87$ & 40,92 & 15 \\
\hline 9 & $\begin{array}{l}\text { Technical University } \\
\text { of Kosice }\end{array}$ & $X$ & \pm & \pm & \pm & \pm & \pm & \pm & \pm & \pm & + & $37 / 23,87$ & 41,57 & 14 \\
\hline 10 & $\begin{array}{l}\text { Constantine the } \\
\text { Philosopher University } \\
\text { in Nitra }\end{array}$ & $\mathrm{X}$ & \pm & \pm & \pm & \pm & \pm & \pm & \pm & \pm & \pm & $28 / 18,06$ & 46,32 & 9 \\
\hline 11 & $\begin{array}{l}\text { Trnava University in } \\
\text { Trnava }\end{array}$ & $\mathrm{X}$ & \pm & \pm & \pm & \pm & \pm & \pm & \pm & \pm & \pm & $28 / 18,06$ & 59,9 & 2 \\
\hline 12 & $\begin{array}{l}\text { University of Zilina in } \\
\text { Zilina }\end{array}$ & $\mathrm{X}$ & \pm & \pm & \pm & \pm & \pm & \pm & \pm & \pm & \pm & $28 / 18,06$ & 45,62 & 11 \\
\hline 13 & $\begin{array}{l}\text { Alexander Dubcek } \\
\text { University of Trencin }\end{array}$ & $\mathrm{X}$ & \pm & \pm & \pm & \pm & \pm & \pm & \pm & \pm & \pm & $28 / 18,06$ & 27 & 20 \\
\hline 14 & $\begin{array}{l}\text { University of } \\
\text { Economics in } \\
\text { Bratislava }\end{array}$ & $\mathrm{X}$ & \pm & \pm & \pm & \pm & \pm & \pm & \pm & \pm & \pm & $28 / 18,06$ & 45,88 & 10 \\
\hline 15 & $\begin{array}{l}\text { Slovak University of } \\
\text { Agriculture in Nitra }\end{array}$ & $\mathrm{X}$ & \pm & \pm & \pm & \pm & \pm & \pm & \pm & \pm & \pm & $28 / 18,06$ & 51,03 & 7 \\
\hline
\end{tabular}




\begin{tabular}{|c|c|c|c|c|c|c|c|c|c|c|c|c|c|c|}
\hline 16 & $\begin{array}{l}\text { Academy of } \\
\text { Performing Arts in } \\
\text { Bratislava }\end{array}$ & $\mathrm{X}=$ & \pm & \pm & \pm & \pm & \pm & \pm & \pm & \pm & \pm & $28 / 18,06$ & 38,1 & 17 \\
\hline 17 & $\begin{array}{l}\text { Academy of Fine Arts } \\
\text { and Design in } \\
\text { Bratislava }\end{array}$ & $X=$ & \pm & \pm & \pm & \pm & \pm & \pm & \pm & \pm & \pm & $28 / 18,06$ & 56,4 & 5 \\
\hline 18 & $\begin{array}{l}\text { Academy of Arts in } \\
\text { Banska Bystrica }\end{array}$ & $x=$ & \pm & \pm & \pm & \pm & \pm & \pm & \pm & \pm & \pm & $28 / 18,06$ & 34,56 & 18 \\
\hline 19 & $\begin{array}{l}\text { Catholic University in } \\
\text { Ruzomberok }\end{array}$ & $x=$ & \pm & \pm & \pm & \pm & \pm & \pm & \pm & \pm & \pm & $28 / 18,06$ & 51,3 & 6 \\
\hline 20 & $\begin{array}{l}\text { Slovak University of } \\
\text { Technology in } \\
\text { Bratislava }\end{array}$ & $x=$ & \pm & \pm & \pm & \pm & \pm & \pm & - & \pm & \pm & $25 / 16,12$ & 41,62 & 13 \\
\hline
\end{tabular}

*ARRA Average in \%: The resulting percentages were assigned to individual universities / colleges based on averaging of the achieved score (average from partial ratings of their faculties) in a comprehensive evaluation of the ARRA Agency for 2013.

**ARRA Ranking position: Placement in the ranking corresponds to the resulting averaged percentages of universities / colleges.)

In determining the sentiment the numbers of positive reviews on social networks were not taken into account. Only the fact that an institution owns a profile on any of the virtual social networks was taken into account. The nature of institutions descriptions on the Wikipedia portal was also not taken into account. Only the fact that Wikipedia mentions an institution was taken into account. In both cases, these results were assigned neutral sentiment. If, besides an official institution's web site, the search engine found web pages of institution's faculties or entities associated with such institution on other positions, these results were assigned neutral sentiments. As the Table 2 presents, the ranking of the researched institutions showed significant differences when comparing real and virtual environments. Paradoxically, while some institutions reached a high sentiment score in the virtual environment, they finished among the last when comparing the sentiment score in the real environment. By applying Kendall coefficient $(\tau)$, which measures the strength of dependence between two serial variables (in this case, reputation in the real and virtual environment), individual rankings of public universities and colleges in the Slovak market were tested. Since the calculated value of tau $(\tau)$ is less than the critical value in the table, we shall not reject the hypothesis of independence at the alpha significance level $\alpha=0.01$, i.e. there is no statistically significant dependence between universities' or colleges' rankings in the case of virtual (online) reputation and rankings in the case of real environment reputation.

\section{Results of the analysis}

Based on the analysis it is clear that within the virtual identity of researched entities (twenty public universities or colleges on Slovak market) web sites owned directly by providers are at the top places of search. The dominant group of sentiments consists of search results of neutral sentiment. There was only one instance of negative sentiment of an institution noted: on the eighth position within the search (Slovak University of Technology in Bratislava was given negative assessment, in relation to fire in the chemical laboratory of the University). Entities that occupy top positions have, in terms of virtual reputation among Internet users, undeniable benefit in the form of a more positive perception of their complex virtual identity. If users search for information about a particular university or college and encounter negative references, it can ultimately affect 
their overall perception of the given institution. Especially if these users do not have any personal experience with a given institution and judge only on the basis of information from the virtual environment. Entities should therefore make sure to make necessary information available to Internet users in the clearest way possible. It is in their own interest to ensure the elimination of negative publicity (and vice versa reinforce positive publicity) for at least the first ten positions in search engines. This can be achieved by active Internet communication policy in the form of spreading positive information on major Internet players, such as electronic versions of major Slovak dailies or through virtual social networks, Internet forums and discussions. The best way to eliminate negative or neutral publicity in the first ten search engine results is a literal displacement of such publicity by actively working on a coherent marketing communications policy on the Internet. The most interesting finding was a demonstration of relatively low percentage of achieved reputation in the online environment considering the high percentage of reputation (ARRA index) achieved within the real world. This points to the fact that over a period of time the very best universities and colleges managed to optimize the factors and processes that have contributed significantly to increase their reputation in the real world but in the virtual environment are still a long way to go. Notional value of $100 \%$ of online reputation (155 points achieved in the sentiment analysis) is, in this case is "only" sort of imaginary, in the virtual world almost unattainable state. With such small differences within the analyzed entities it also possible to achieve a significant progress towards top positions against competition exerting fewer resources (financial, time, human). As already mentioned, the methodology presented is one of many methodologies used for the assessment and measurement of online reputation. Its complexity, clarity and relatively low time demandingness predisposes it to be used for the purpose of assessment of online reputation of various entities such as public institutions acting in various field, companies and even individuals using the Internet for purpose of personal branding.

\section{Summary}

The current hyper informational time puts high demands on individuals as well as the whole society. Highly specialized power elites take the lead with the help of new technologies. Building and promoting a quality brand and the related good repute requires application of the right marketing tools. Nowadays, there are innumerable ways in which a subjects share information with their environment. However, building brand credibility is influenced by many factors that management is not always able to have under control. The aim of the paper was to highlight the importance of reputation in the online world in comparison with the real world in the area of public universities and colleges operation in the Slovak market. Compiled reputation levels ranking of Slovak universities and public colleges show substantial differences. Statistically significant dependence between ranking based on the reputation in the real and virtual market was not confirmed. The result of the perception of reputation, also on the basis of this paper, may be a good and targeted communication, which is part of the marketing mix. Positive reputation, especially in the online environment of immediate decisions, is often the critical factor for customers. In addition to long-term building of positive image it is therefore important to regularly verify the level of reputation and eliminate negative news to constantly form a positive customer experience with an institution. As we mentioned, the very best universities and colleges managed to optimize the factors and processes that have contributed significantly to increase their reputation in the real world but in the virtual environment are still a long way to go. 
This article is one of the partial outputs of the currently solved research grant VEGA no. 1/0145/14 entitled "Online reputation management (ORM) as a tool to increase competitiveness of Slovak SMEs and its utilization in conditions of Central European virtual market".

\section{References}

1. V. Janouch, 333 tipů a triků pro internetový marketing. Brno: Computer Press (2011).

2. H. Marsden, Guard Your Reputation On-line. Birmingham: Smartebookshop (2013).

3. R. Haywood, Manage Your Reputation: How to Plan Public Relations to Build \& Protect the Organization's Most Powerful Asset. London: Kogan Page Publishers (2002).

4. A. Griffin, New Strategies for Reputation Management: Gaining Control of Issues, Crises \& Corporate Social Responsibility. London: Kogan Page Publishers (2008).

5. J. Balmer, and S. Greyser, Revealing the Corporation: Perspectives on Identity, Image, Reputation, Corporate Branding and Corporate-level Marketing, Oxford: Routledge (2003).

6. S. Helm, K. Liehr-Gobbers, and Ch. Storck, Reputation Management. Berlin: Springer-Verlag (2011).

7. $\quad$ P. Gottschalk, Corporate Social Responsibility, Fovernance and Corporate Reputation. USA: World Scientific Publishing Co. Pte. Ltd. (2011).

8. D. A. Shore, The Trust Prescription for Healthcare: Building Your Reputation with Consumers. USA: Health Administration Press (2005).

9. M. Armstrong, Handbook of Human Resource Management Practice, 10th ed., Prague Grada Publishing, (2007).

10. M. Tavakolifard, On Some challenges for On-line Trust and Reputation Systems (2012) <http://www.diva-portal.org/smash/get/diva2:548911/FULLTEXT02>

11. D. Gambetta, "Can We Trust Trust?" (2000) [doi: 10.1.1.24.5695].

12. A. Jøsang, R. Ismail, and C. Boyd, "Survey of Trust and Reputation Systems for Online Service Provision," in QUT ePrints (2006)

$\langle$ http://eprints.qut.edu.au/7280/1/7280.pdf>

13. J. Sabater, and C. Sierra, Review on Computational Trust and Reputation Models. (2003) <http://www.iiia.csic.es/ sierra/articles/2005/SabaterSierra.pdf>

14. G. Leboff, Sticky marketing - Jak zaujmout, ziskat a udržtet si zákazníky. Prague Management Press (2011).

15. I. Smaiziene, and R. Jucevicius, "Corporate Reputation: Multidisciplinary Richness and Search for a Relevant Definition," in Inzinerine Ekonomika-Engineering Economics. 91-101 (2009).

16. K.T. Jackson, Building Reputational Capital: Strategies for Integrity and Fair Play that Improve the Bottom Line. USA: Oxford University Press (2004).

17. C. Fill, Marketing Communications: Interactivity, Communities and Content, 5 th ed. UK: Pearson Education Ltd. (2009).

18. R. Rohál', and J. Sasko, Analýza sentimentu výsledkov slovenských firiem. Visibility s.r.o. (2011) <http://www.reputation.sk/whitepapers/Analyza_sentimentu_reputation_sk.pdf $>$

19. C. J. Fombrun, and C. B. Foss, "The Reputation Quotient, Part 1: Developing a Reputation Quotient," (2001)

<http://www.reputationinstitute.com/frames/press/01_15_14_GUAGE.pdf>

20. G. Walsh, and S. Beatty, "Customer-based Corporate Reputation of a Service Firm," in Journal of the Academy of Marketing Science, Vol 35, No 1, 127-143 (2007).

21. R. J. Burke, and C. L. Cooper, Corporate Reputation: Managing Opportunities and Threats, UK: Gower Publishing Ltd. (2011). 
22. A. Siano, A. Vollero, and M. Pallazo, "Exploring the Role of On-line Consumer Empowerment," in Reputation Building: Research Questions and Hypotheses. (2011) <http://www.academia.edu/1096337/Exploring_the_role_of_on-

line_consumer_empowerment_in_reputation_building_Research_questions_and_hypothes es>

23. T. Henning-Thueau, K. P. Gwinner, G. Walsch, and D.D. Glemler, "Electronic Wordof-mouth Via Consumer-opinion Platforms: What Motivates Consumers to Articulate Themselves on the Internet? " $(2004)<$ http://www.gremler.net/personal/research/2004_Electronic_WOM_JIM.pdf>

24. J. Loayza, The Beginner's Guide to Reputation Management: 8 Core Principles of Reputation Management. (2013) <http://reputationhacks.com/guide-to-reputationmanagement-3-8-core-principles/>

25. Academic Ranking and Rating Agency (ARRA), Hodnotenie fakúlt vysokých škôl 2013, (2013) <http://www.arra.sk /ranking-2013>

\section{Caption List}

Table 1 Sentiment individual results / position of results.

Table 2 Total score sentiments twenty Slovak public universities / colleges. 